\title{
Mechanism of long-standing Cenozoic basin formation in central Hokkaido: an integrated basin study on an oblique convergent margin
}

\author{
Yasuto Itoh ${ }^{1 *}$, Osamu Takano ${ }^{2}$, Shigekazu Kusumoto ${ }^{3}$ and Machiko Tamaki ${ }^{4}$
}

\begin{abstract}
The basin-forming process along a convergent margin off the eastern coast of Eurasia was pursued on the basis of geological, geochemical, and geophysical approaches. Central Hokkaido has been a site of vigorous tectonic events throughout the Cenozoic reflecting the long-standing subduction of oceanic plates in the region. Geochemical modeling provided an estimate of the eroded Paleogene unit in the study area. Data on the considerable thickness of the missing unit implied continued subsidence of the forearc region and its subsequent exhumation under the emergence of a compressive regime synchronous with the back-arc opening stage. Spatially large facies variety in the Paleogene system suggests that basin compartmentalization occurred as a result of the trench-parallel component of the plate convergence. Right-lateral motion seems to have been the dominant type in Hokkaido and the forearc of northeast Japan since the Late Cretaceous, except for a left-lateral episode during rapid subsidence of the Izanagi Plate around $110 \mathrm{Ma}$. Numerical modeling demonstrated that dextral slip on a bunch of longitudinal strike-slip faults restored the Neogenedepocenters in central Hokkaido, together with an east-west compressive regime related to an arc-arc collision.
\end{abstract}

Keywords: Basin subsidence; Foreland basin; Modeling; Strike-slip basin; Subduction-related basin; Tectonics and sedimentation; Geochemistry; Maturation; Hokkaido

\section{Background}

Hokkaido is an island presently located at a junction of the Kurile arc and northeast Japan arc (Figure 1). Reflecting active deformation on the Eurasian margin, voluminous and various types of sedimentary basins have emerged in the island through the Cenozoic. This region is an example of basin evolution controlled by the transition of tectonic regimes. The authors aim to better understand the causal relationship between dominant tectonic modes and styles of sedimentary basins, and such work is pursued by utilization of geological, geophysical, and geochemical information. Our main

\footnotetext{
* Correspondence: yasutokov@yahoo.co.jp

'Department of Physical Science, Graduate School of Science, Osaka

Prefecture University, Gakuencho 1-1, Naka-ku, Sakai, Osaka 599-8531, Japan

Full list of author information is available at the end of the article
}

focus here and elsewhere was on the central N-S elongated depression adjacent to the arc-arc collision front of the Hidaka Mountains, which is collectively named as the Ishikari-Teshio Belt.

Cenozoic strata in the Ishikari-Teshio Belt, which roughly coincides with the Sorachi-Yezo Belt in the Mesozoic tectonic architecture (Figure 1), are underlain by the Cretaceous Yezo Group that is regarded as a typical sequence in a forearc basin setting (Ando 2003). Compared to monotonous fine sediments of the Yezo Group, the Paleogene system has a large variety of sedimentary facies. We interpret this diversity as being related to the deformation of the forearc by transcurrent fault motions, which has been described on the basis of seismic interpretations. Intricate tectonic events since the Neogene, such as backarc spreading, arc-arc collisions, and hypothetical differential rotation of crustal 


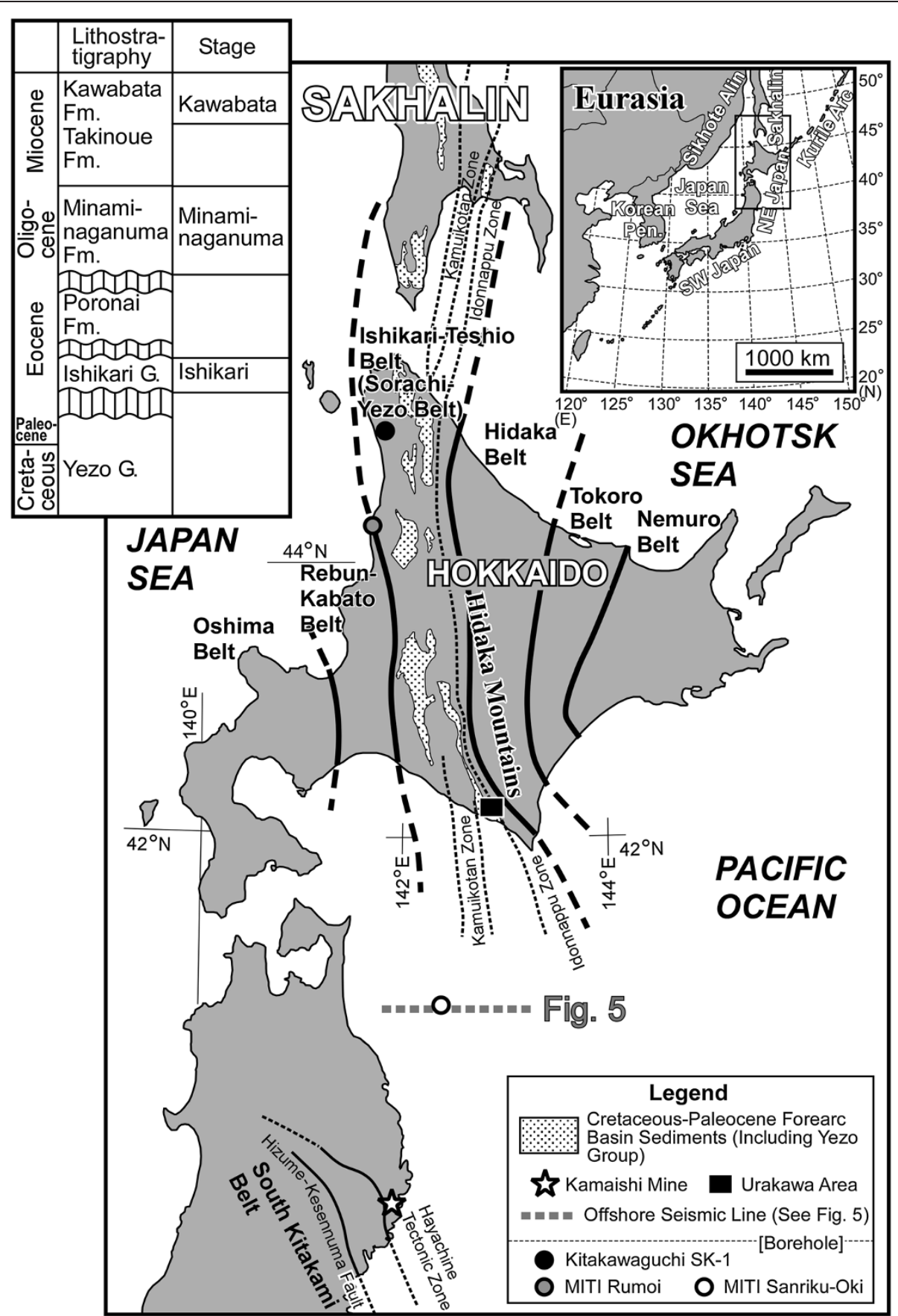

Figure 1 An index map of tectonics and the basin configuration around Hokkaido. The location of the seismic profile in Figure 5 is shown by a dotted gray line on the forearc of northeast Japan.

blocks, should affect the basin-forming process in the Ishikari-Teshio Belt and regional mass balance on the east Eurasian convergent margin. In this paper, we describe significant geological events in the study area, which includes the Ishikari-Teshio Belt and forearc region of northeast Japan (Figure 1), under the same tectonic regime through the Cenozoic. Together with integrated review of basin analyses, our original geochemical data and basin modeling pave a path to the most probable tectonic history of the study area.

\section{Methods}

Spatio-temporal distribution of Paleogene sediments

Paleogene central Hokkaido was a site of vigorous basin formation. Although geologic studies have shown the spatio-temporal distribution of these basins (Figure 2), 


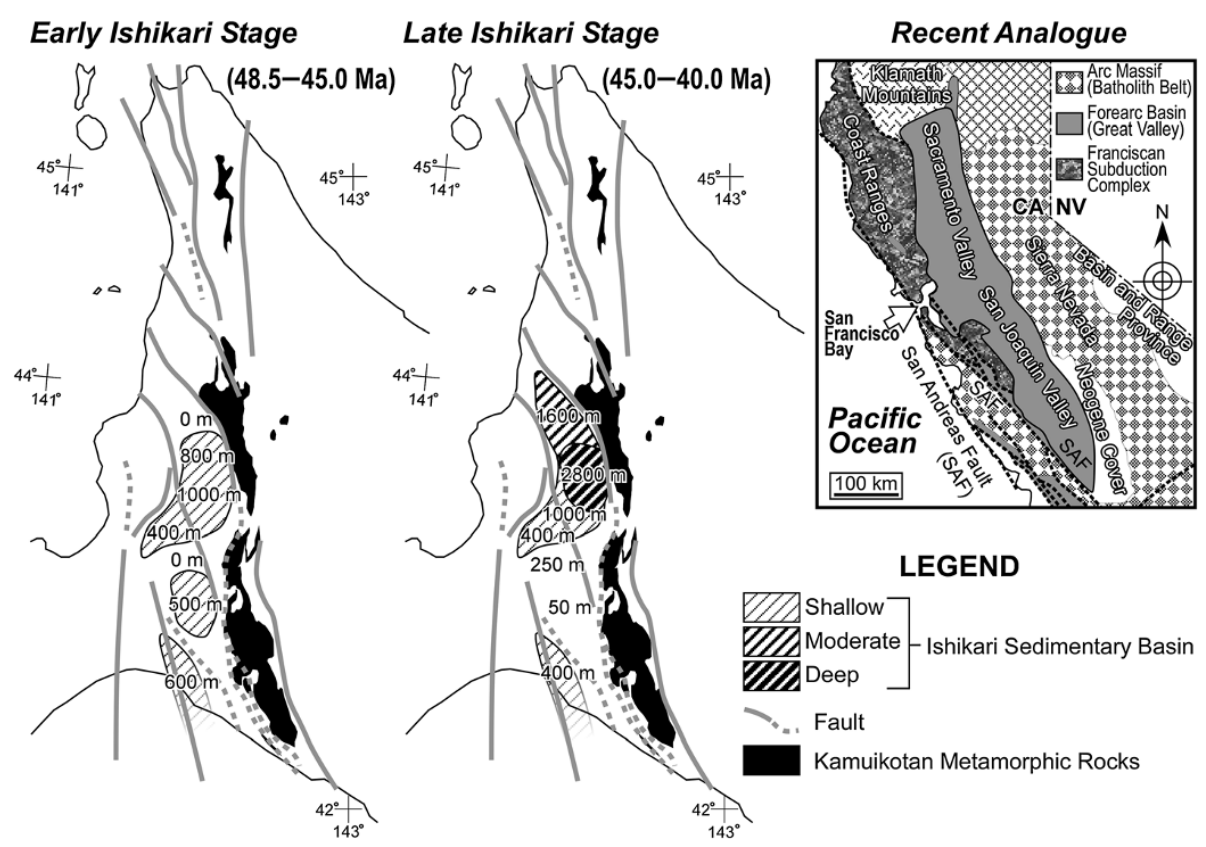

Figure 2 Configuration of the Paleogene Ishikari sedimentary basin. Numbers attached on basins show sediment thickness in meters, which were compiled after surface information and borehole stratigraphic data (Kusumoto et al. 2013). Tectonic map around California as a recent analogue (inset) is after Dickinson and Seely (1979).

later erosion during the remarkable contraction regime of the Neogene may have obscured the total volume of sediments. Hence, we examined maturation profiles of organic matter derived from sedimentary rocks and attempted to reconstruct the burial history based on kinetic models. On the coast of the Japan Sea, a geochemical database derived from two exploration boreholes (Figure 1) was adopted for use in the present study. From the southernmost tip of the Ishikari-Teshio Belt, geochemical samples were taken from surface outcrops with datum planes (Gradstein et al. 2012). Our analytical procedures are presented in the following sections.

\section{Geochemical analyses}

In order to determine the total history of basin burial, we executed one-dimensional modeling of maturation levels of organic matter contained in the Cretaceous Yezo Group. On the trench side of the Paleogene forearc region, samples were taken along the Chinomigawa River route in the Urakawa area (Figures 1 and 3). On the continental side of the coeval forearc region, maturation data of deep boreholes (Kitakawaguchi SK-1 and MITI Rumoi; see Figure 1) were utilized. As for the samples from the Chinomigawa route, geochemical analyses were performed in the Research Center of JAPEX (Japan Petroleum Exploration Co., Ltd.), the procedures of which are explained in sections 'Rock-eval pyrolysis', 'Total organic carbon', and 'Vitrinite reflectance'.

\section{Rock-eval pyrolysis}

Bulk rock pyrolysis analysis was carried out using the VINCI Rock-Eval 6 to obtain $T_{\max }$ values for each sample. Samples were crushed to a powder in an auto-mill and dried overnight at $60^{\circ} \mathrm{C}$ in a desiccator. After weighing out about $100 \mathrm{mg}$ of powdered sample in a container, the dried samples were heated under nitrogen gas at $300^{\circ} \mathrm{C}$ for $3 \mathrm{~min}$, and then the temperature was increased by $25^{\circ} \mathrm{C} / \mathrm{min}$ up to $650^{\circ} \mathrm{C}$ and held isothermally for $1 \mathrm{~min}$. The generated organic compounds and $\mathrm{CO}_{2}$ were measured with a flame ionization detector and thermal conductivity detector, respectively. Samples were analyzed using an apparatus that was calibrated with an IFP Energies nouvelles standard. All $T_{\max }, S_{1}, S_{2}$, and $S_{3}$ values are listed in Table 1, and typical pyrograms are presented in Figure 3a.

\section{Total organic carbon}

As for bulk analysis samples, total organic carbon (TOC) was measured using a CHN determinator (J-Science LAB JM10, Kyoto, Japan). Samples were powdered and dried as mentioned before. After weighing out about $3 \mathrm{mg}$ of the samples, they were treated with $6 \mathrm{~N} \mathrm{HCl}$ for an hour to remove carbonate minerals. Decalcified samples were then dried in an oven at $60^{\circ} \mathrm{C}$ for 2 days and stored in a desiccator. Dried samples were poured into tin containers and analyzed with the $\mathrm{CHN}$ determinator. The TOC data are listed in Table 1. 


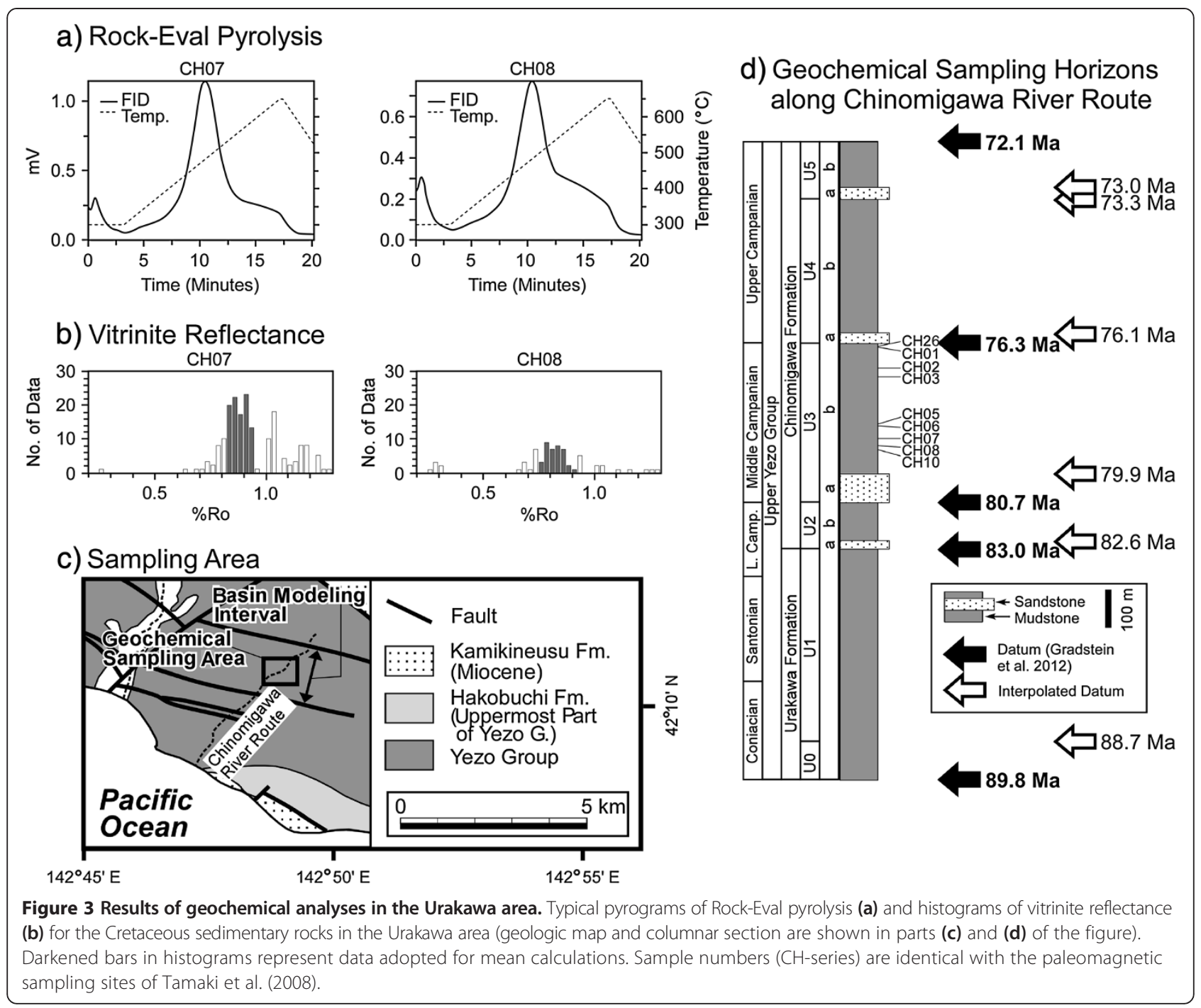

Table 1 Rock-eval pyrolysis, total organic carbon (TOC), and vitrinite reflectance data for the study areas

\begin{tabular}{|c|c|c|c|c|c|c|c|}
\hline Sample ID & Depth (m) & $T_{\max }\left({ }^{\circ} \mathrm{C}\right)$ & $S_{1}(\mathrm{mg} / \mathrm{g})$ & $S_{2}(\mathrm{mg} / \mathrm{g})$ & $S_{3}(\mathrm{mg} / \mathrm{g})$ & TOC (wt.\%) & $\%$ Ro \\
\hline \multicolumn{8}{|c|}{ Chinomi-gawa section } \\
\hline $\mathrm{CH} 26$ & 533 & 442 & 0.05 & 0.89 & 0.33 & 0.96 & 0.69 \\
\hline $\mathrm{CH} 01$ & 535 & 443 & 0.02 & 0.61 & 0.32 & 1.00 & 0.78 \\
\hline $\mathrm{CH} 02$ & 590 & 434 & 0.02 & 0.27 & 0.14 & 0.62 & 0.83 \\
\hline $\mathrm{CHO3}$ & 613 & 437 & 0.02 & 0.23 & 0.23 & 0.57 & 0.83 \\
\hline $\mathrm{CH} 05$ & 738 & 436 & 0.02 & 0.33 & 0.21 & 0.63 & 0.73 \\
\hline $\mathrm{CH} 06$ & 741 & 439 & 0.05 & 0.54 & 0.21 & 0.90 & 0.86 \\
\hline $\mathrm{CH} 07$ & 773 & 440 & 0.02 & 0.38 & 0.19 & 0.93 & 0.89 \\
\hline $\mathrm{CH} 08$ & 792 & 440 & 0.02 & 0.26 & 0.24 & 0.70 & 0.82 \\
\hline $\mathrm{CH} 10$ & 802 & 438 & 0.02 & 0.31 & 0.22 & 0.74 & 0.84 \\
\hline
\end{tabular}




\section{Vitrinite reflectance}

Visual kerogen analyses were conducted on selected samples using a Carl Zeiss MPM-03 microspectrophotometry system (Oberkochen, Germany). Coarsely crushed samples (25 g) were first treated with $\mathrm{HCl}$ for $2 \mathrm{~h}$ to remove carbonates and $\mathrm{HF}$ and $\mathrm{HCl}$ for $4 \mathrm{~h}$ on a hot plate at $97^{\circ} \mathrm{C}$ twice to remove silicate minerals. After 1 week, the solution was centrifuged with heavy liquid to separate kerogen. The kerogen was embedded in a resin plug and polished to a flat shiny surface. Measurements of the percentage of incident light reflected from vitrinite particles under oil immersion were conducted using Carl Zeiss MPM-03 at a magnification of $\times 500$. Reflectance with a digital indicator was calibrated on a glass standard in oil. Vitrinite reflectance data (\% Ro) are listed in Table 1, and typical histograms are shown in Figure $3 \mathrm{~b}$.

\section{Basin modeling}

To understand burial and exhumation histories of the studied sections, thermal and kinetic modeling was performed using BasinMod 1-D ${ }^{\circ}$ software at the Technology Research Center of JOGMEC (Japan Oil, Gas and Metals National Corporation, Tokyo, Japan). Additionally, JAPEX in-house basin modeling software $\mathrm{BSS}^{\odot}$ was used. The $T_{\max }$ data of the Rock-Eval pyrolysis were converted to vitrinite reflectance (\% Ro) data by referring to a built-in conversion table, and then these data were utilized for the maturation modeling. Kinetic models of \% Ro data adopted for the programs are after Suzuki et al. (1993; Simple-Ro) and Sweeney and Burnham (1990; Easy-Ro).

At the present time, we do not have clear geologic evidence to adopt a variable heat-flow model. Therefore, we adopted a constant heat-flow model for the whole modeling period, which extended from the Cretaceous to the present, as the first step of the modeling process. Scarce volcanic material in the sedimentary units in Urakawa implies that the geothermal province of the inner arc was far from our study area during the analyzed period; hence, present-day data of $40 \mathrm{~mW} / \mathrm{m}^{2}$ that were calculated on the basis of temperature logging and thermal conductivity records at a drilling site in central Hokkaido (Tamaki et al. 2009) were adopted for use in this study. As for the Kitakawaguchi SK-1 and MITI Rumoi, a constant value of $48 \mathrm{~mW} / \mathrm{m}^{2}$ (20\% higher than Urakawa) was adopted through the consideration of prolonged igneous activities within the adjacent Rebun-Kabato Belt.

\section{Results}

Results of one-dimensional thermal and kinetic modeling are shown in Figure 4. As for the trench side of the forearc region, modeling results clearly indicate that subsurface temperatures determined for the present thickness of the analyzed rock units did not match those of the measured maturation levels. An eroded younger unit overlying the existing strata is, then, necessary to fit the calculated and observed maturation levels. First, we assumed that the Maastrichtian Hakobuchi Formation, the stratigraphic age of which is based on the unit distributed to the south of the study area (Sakai and Kanie 1986), was deposited on the studied section because it was the uppermost member of the Yezo forearc basin described by Ando (2003). The Hakobuchi Formation shows upward-coarsening facies successions formed by progradation of the inner shelf to delta plain systems (Ando 2003), and these were categorized to be outer to inner shelf, shoreface, subordinate estuary, incised valley, river-channel, back-marsh, and floodplain after Takashima et al. (2004). Next, the forearc basin was probably uplifted in the early Paleocene as a result of voluminous accretion beneath the subduction zone (e.g., Ueda et al. 2000). Burial history of the Hakobuchi Formation (Figure 4a) optimized on the basis of maturation profiles of Ro and $T_{\max }$ (Figure $4 \mathrm{~b}$ ) within the upper part of the Yezo Group indicates an extremely high sedimentation rate $(1.57 \mathrm{~m} / 1,000$ years $)$, which seems to be unrealistic considering the abovementioned sedimentary facies. Therefore, we introduced a missing Paleogene-to-Neogene unit as presented in Figure 4c. This model includes moderate burial/erosion around the end of the Cretaceous, which was practically ineffective at matching the observed maturity and subsequent long-standing subsidence. As the exhumation process was not obvious, the hypothetical strata is assumed to have been removed at a constant rate since the collision and contraction scheme emerged around central Hokkaido at around $15 \mathrm{Ma}$ (Miyasaka et al. 1986). Optimization of the maturation trend (Figure 4d) required an enormous amount of sediment (thickness is ca. 3,300 $\mathrm{m}$ ) accumulation around the Urakawa area during the Paleogene and early Neogene. This result is quite similar to previous modeling in an adjacent area (Tamaki et al. 2009).

In sharp contrast, the one-dimensional modeling for the continental side of the forearc region (Figure 4e,f,g,h) suggests that basin subsidence had been stagnant throughout the late Paleogene, whereas the Neogene period was characterized by drastic subsidence at around $15 \mathrm{Ma}$. This result is concordant with seismic interpretation data of the Japan Sea side of northern Hokkaido (Itoh et al. 2009), which showed an episode of regional subsidence and change in the basin configuration related to Miocene back-arc spreading. Therefore, our geochemical approach has confirmed the presence of a tectonic episode of extensive longitudinal basin formation during the Paleogene.

\section{Discussion}

Our geochemical analysis has revealed a dynamic process of burial and exhumation in the study area. The authors present a chronicle of the Cenozoic basin formation and 
a)

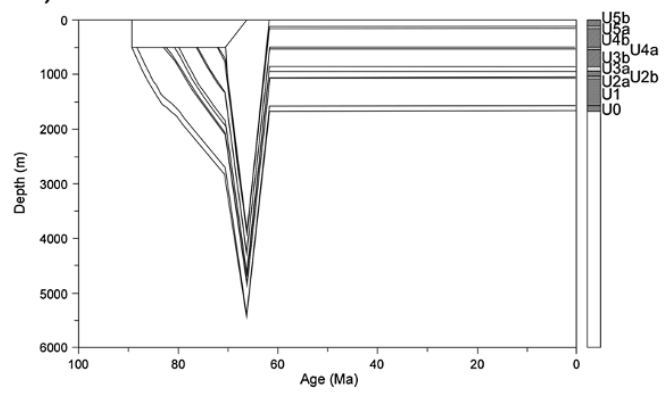

c)

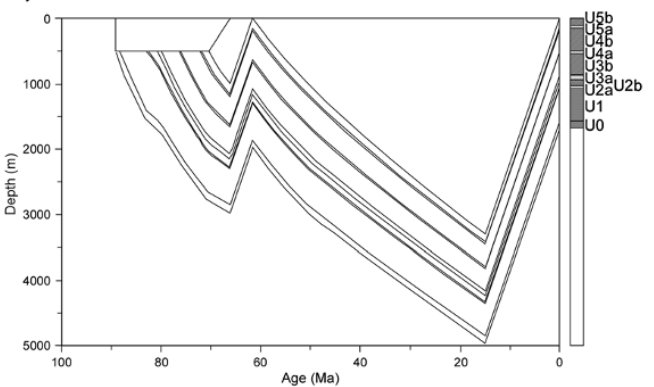

e)

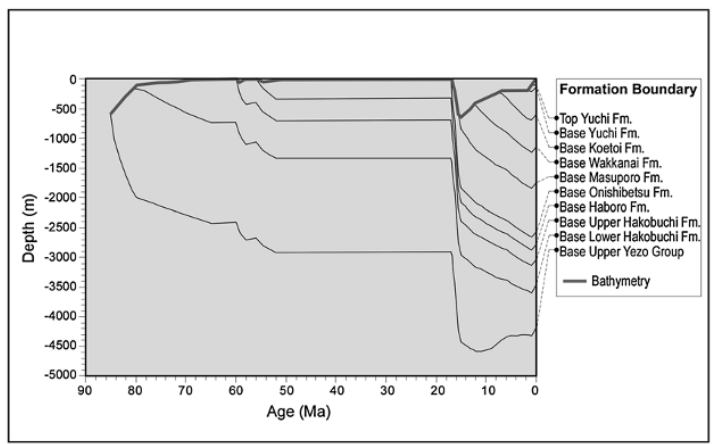

g)

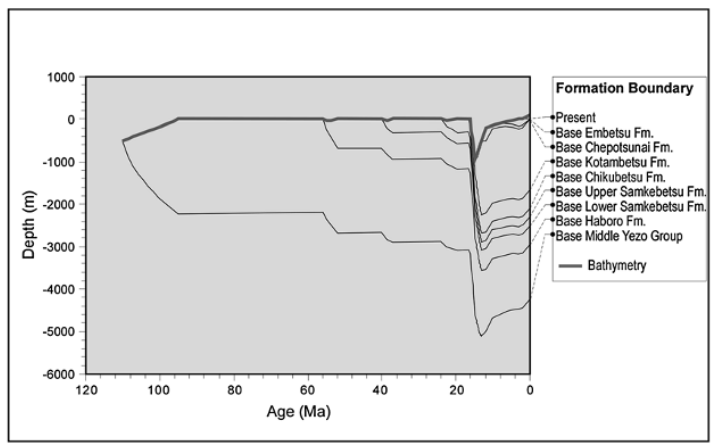

b)

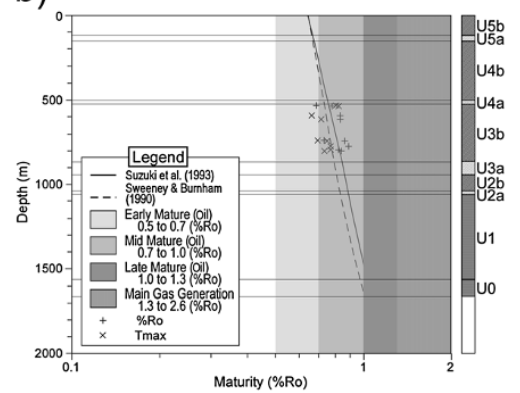

d)

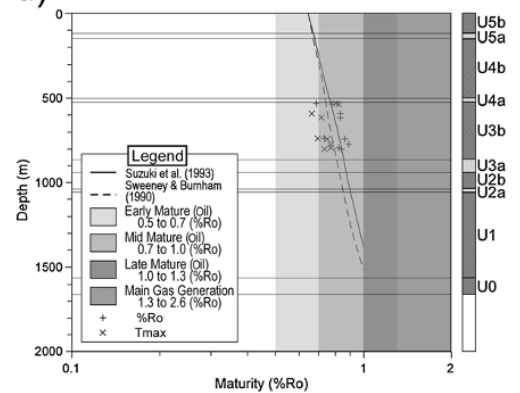

f)

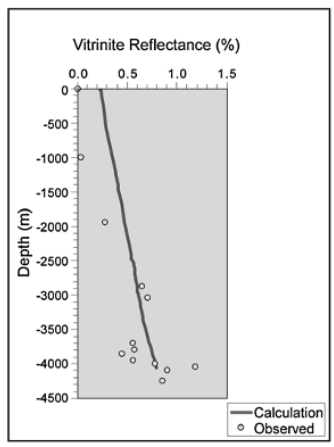

h)

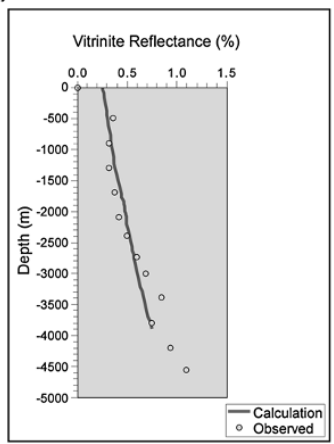

Figure 4 Results of one-dimensional thermal and kinetic modeling. Models for the trench side $(\mathbf{a}, \mathbf{b}, \mathbf{c}, \mathbf{d})$ and continental side (e, $\mathbf{f}, \mathbf{g}, \mathbf{h})$ of the paleo-forearc region in Hokkaido. (a) Burial history assuming drastic burial (deposition of the Hakobuchi Formation) and exhumation (development of the Horobetsugawa Complex) around the end of Cretaceous and early Paleocene, respectively (Model 1). (b) Measured (dots) and calculated (lines) maturation trends optimized for Model 1. (c) Burial history assuming Paleogene persistent subsidence and Neogene exhumation (Model 2). (d) Measured (dots) and calculated (lines) maturation trends optimized for Model 2. (e) Burial history for the Kitakawaguchi SK-1 borehole. (f) Measured (dots) and calculated (line) maturation trends optimized for the Kitakawaguchi SK-1. (g) Burial history for the MITI Rumoi borehole. (h) Measured (dots) and calculated (line) maturation trends optimized for the MITI Rumoi. 
related tectonic episodes in the following sections. Then, we evaluate tectonic models for the development of the convergent margin in the light of re-examination of the paleomagnetic data and numerical modeling of basin formation.

\section{Early Paleogene setting}

We divided the Paleogene into two stages based on the tectonic context. The middle Eocene setting consists of an initiation of sedimentary basins, and the late Oligocene setting represents a transition to a remarkable transpressional regime on the convergent margin. Sedimentary units in between periods (e.g., Poronai and Momijiyama Formations) have significance for the construction of a paleoenvironmental overview, and numerical modeling of basin formation has been conducted for the Poronai stage (Kusumoto et al. 2013). However, their subsurface distribution needs to be reassessed on the basis of updated biostratigraphic information; hence, we excluded these units from the basin analysis in the present study.

After sporadic basin formation during the Paleocene, the Eocene Ishikari Group in a bay-to-fluvial environment was deposited extensively in the Ishikari-Teshio Belt. Based on the mineral assemblage, Iijima (1959) showed that sand grains of the Ishikari Group were derived from the Kamuikotan metamorphic rocks on the trench side (east) of the depositional areas, a fact which is suggestive of uplift and erosion of the trench slope break on the forearc. The isolated basin of the Ishikari Group was probably connected with the open marine environment by narrow inlets, a recent analogue of which can be seen in the present Sacramento Valley that connects with the Pacific Ocean at San Francisco Bay in California (inset map of Figure 2). It represents the 'shelved (shallow marine)' or 'benched (terrestrial)' type of forearc after Dickinson (1995). Takano et al. (2013) presented a schematic and conceptual forearc setting model for the Eocene Ishikari basin.

It should be noted here that the sedimentary basin of the Ishikari Group was differentially subsided and can be divided into several compartments (Takano and Waseda 2003). Figure 2 delineates a plan view of the Ishikari subbasins. As a modern analogue, similar compartmentalization can be observed on the Sunda forearc, where an oblique subduction setting is prevalent (Dickinson 1995). To the south of our study area, the contemporaneous forearc basin of northeast Japan seems to have suffered similar segmentation, and wrench deformation on this region was inferred from paleomagnetic data. Itoh and Tsuru (2006) reported paleomagnetic directions from a borehole on the forearc (MITI Sanriku-oki in Figure 1), which are suggestive of clockwise rotation since the Eocene, and proposed a tectonic model of forearc slivers divided by dextral faults.
Another characteristic of the Eocene basin is acceleration of subsidence. Based on a detailed sedimentological study, Takano and Waseda (2003) pointed out that the rate of subsidence had accelerated during deposition of the Ishikari Group. A contractional regime may have been coexistent during this stage, as was suggested by Takano et al. (2013) and Kusumoto et al. (2013). Kawakami et al. (2002) found fragments of metamorphic rocks from acidic tuff intercalated in a lower Oligocene unit in the IshikariTeshio Belt. A low-pressure and high-temperature type of metamorphic material implies considerable uplift and exhumation of the Hidaka Mountains. Existence of acidic tuff layers also suggests that subduction-related volcanism was still active. An Eocene geologic unit linked to an accretion episode was described by Kawakami et al. (2008). Thus, formation/deformation processes of the early Paleogene basins were probably governed by active subduction and transpressional motion on the N-S margin.

\section{Late Paleogene setting}

Regional unconformity: seismic interpretation

As predicted by Fitch (1972), prevailing oblique subduction upon the ancient forearc region may have provoked the development of a bisecting transcurrent fault parallel to the trench axis. Its modern analogue can be seen in the Barisan fault in the Sunda arc (Dickinson 1995). The southern part of the possible bisecting fault system was described by Itoh and Tsuru (2006). They found strike-slip faults within the northeast Japan forearc based on seismic interpretations. In this area, a remarkable Oligocene unconformity was found and named as 'Ounc' by Osawa et al. (2002). Because the angular unconformity is recognized along the most conspicuous fault on the forearc, this regional uplift and erosion event was probably linked to activation of dextral motions on the fault system.

Figure 5 shows an E-W seismic profile acquired in a MITI survey (JNOC 1974), which crossed the modern forearc of northeast Japan. The profile is characterized by numerous high-angle faults, on which transcurrent motions can be assumed from the viewpoint of regional structural architecture. Recent seismic investigations have visualized intensive deformation of the early Paleogene units cut by the 'Ounc' unconformity. Osawa et al. (2002) and Takano et al. (2013) assigned the 'Ounc' to the base of the Minaminaganuma Formation, which deposited in a large pull-apart sag in Hokkaido as described in the next section. The presence of several regional unconformities implies recurrent activities of the arc-bisecting fault system and progressive deformation of the forearc region.

\section{Description of pull-apart basins}

The late Paleogene structural style around Hokkaido is different from that in the northeast Japan forearc. Depocenters are aligned on the transcurrent fault system in 


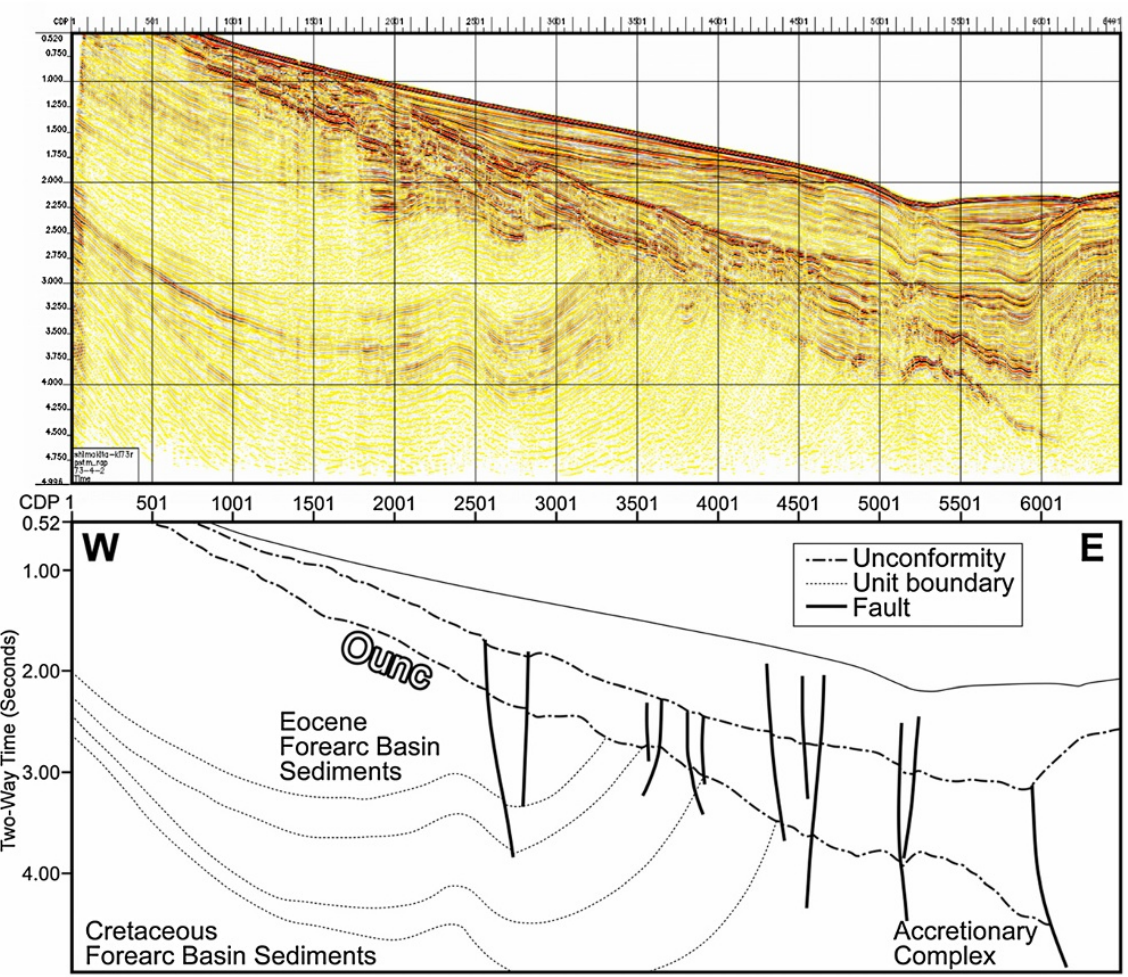

Figure 5 An E-W seismic profile crossing transcurrent faults on the northeast Japan forearc region. Data were acquired in a MITI survey (JNOC 1974). See Figure 1 for line location. Geologic interpretation is after Takano et al. (2013).

conjunction with stepover portions of fault trace. From north to south, Itoh et al. (2009), Tamaki et al. (2010), and Itoh and Tsuru (2005) described synchronously developed pull-apart basins in the Ishikari-Teshio Belt. Among them, the Minaminaganuma basin, which is buried by the late Oligocene Minaminaganuma Formation (Kurita and Yokoi 2000) that is intercalated with numerous volcaniclastic layers (T2 and T3 zones in Figure 6), is the largest depression (Figure 7; southern basin in Minaminaganuma stage with maximum thickness of 2,000 m). Tamaki et al. (2010) executed dislocation modeling of the pull-apart basin and clarified that a $30-\mathrm{km}$ right-lateral strike slip is required to restore the actual distribution and volume of the basin. As the northernmost member of a series of tectonic basins, the Oligocene Magaribuchi Formation developed in a wedge-shaped depression (maximum thickness 1,500 m; Figure 7) under transcurrent motions of faults on the basin margins (Kurita 2010). Therefore, the pull-apart basin formation was a regional tectonic episode along the eastern Eurasian margin.

\section{Unique forearc volcanism}

Kurita and Yokoi (2000) showed that the Minaminaganuma Formation consists of a lower volcanic unit and an upper clastic unit. Figure 6 (top) depicts the radiometric age histogram obtained from late Oligocene and early Miocene volcanic/volcaniclastic rocks in the southern part of the Ishikari-Teshio Belt. The presence of volcanic material in central Hokkaido is an anomalous phenomenon because the coeval (approximately $30 \mathrm{Ma}$ ) volcanic front of northeast Japan was located on the eastern margin of the Japan Sea (Tatsumi et al. 1989). Based on a geochemical study of Takinoue volcanic rocks, which are included in the Takinoue Formation and Minaminaganuma Formation (Figure 1), Okamura et al. (2010) argued that the anomalous volcanism was related to the opening event of the Japan Sea. They also pointed out a linkage between the distribution of volcanic rocks and N-S trending coeval transcurrent faults. Niida (1992) noted that alkali igneous rocks with a high $\mathrm{Na}_{2} \mathrm{O} / \mathrm{K}_{2} \mathrm{O}$ ratio occur in restricted areas along transform boundaries, as exemplified by the modern Andaman arc setting. Figure 6 (lower) depicts the geochemical plot for the Mesozoic (Niida 1992) and Oligocene-Miocene (Okamura et al. 2010) volcanic rocks in southern central Hokkaido. The compositional trend of the OligoceneMiocene (Takinoue) volcanic rocks is in accord with that observed in Grenada, which is located in the vicinity of a major transform plate boundary (Niida 1992). Therefore, activation of the dextral strike-slip movement and formation of a pull-apart basin may have 


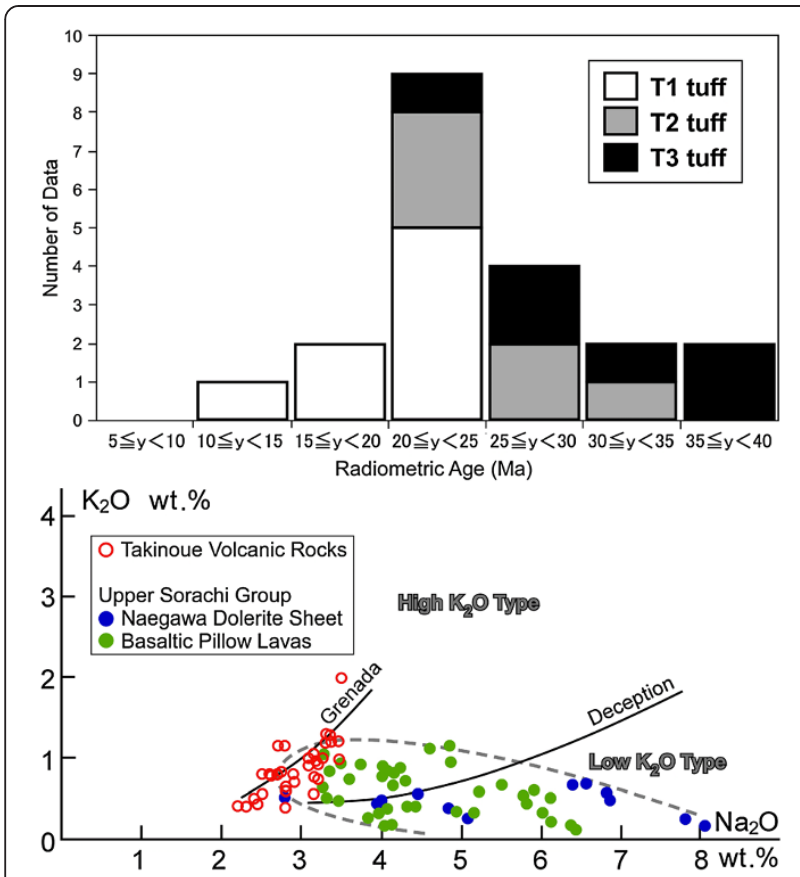

Figure 6 Characteristics of the volcanism in central Hokkaido. Top: histogram of radiometric ages (courtesy of JAPEX, the Japan Petroleum Exploration Co. Ltd., using the relevant subsurface data set) obtained from the late Oligocene and early Miocene volcanic/ volcaniclastic rocks in the southern part of the Ishikari-Teshio Belt. Bottom: geochemical trends of the Mesozoic Sorachi Group (Niida 1992) and the Oligocene-Miocene volcanic rocks (Takinoue; Okamura et al. 2010) in central Hokkaido.

resulted in the formation of a deep crustal rupture and episodic volcanism.

\section{Neogene setting}

\section{Sedimentary environment during opening of the Japan Sea} backarc basin

The Neogene of Japan was heralded by the opening event of the Japan Sea back-arc basin. There are two kinematic models of back-arc opening. One is a 'double-door' model based upon paleomagnetism (Otofuji and Matsuda 1983; Otofuji et al. 1994), and the other is a 'pull-apart' model deduced from regional tectonics (Lallemand and Jolivet 1985). The former model requires counterclockwise rotation and extensional deformation of Hokkaido adjacent to a pivot of the northern 'door' (a drifted coherent landmass). The latter model causes clockwise rotation of domino-style crustal blocks (Takeuchi et al. 1999) in Hokkaido that are situated on a dextral margin of the large rhomboidal back-arc basin. A paleomagnetic study by Tamaki et al. (2010) indicates that these simplistic models cannot account for complicated deformation in Hokkaido. Furthermore, seismic data (e.g., Itoh et al. 2005) indicate intensive deformation and detachment in the upper crust of the Ishikari-Teshio Belt.
Among the Neogene sedimentary units in Hokkaido, lithology of the Takinoue Formation seems to reflect environmental changes during the regional back-arc opening. The lower part of the Takinoue Formation consists of marine sediments in a transgression/regression cycle accompanied with voluminous volcanic material, whereas the upper part was deposited in a transgressive episode and gradually changed into turbidite facies of the overlying Kawabata Formation. Although the lower (ca. 18 to 19 $\mathrm{Ma})$ and upper ( $<18 \mathrm{Ma}$ ) parts of the formation may represent rifting under a transtensional regime and development of elongate basins along the large strike-slip fault system, respectively, further investigations of the stratigraphy and sedimentary facies will be necessary to elucidate the tectonic context of this intriguing unit.

\section{Prevalence of foreland basin setting}

Miyasaka et al. (1986) proposed that uplift and massive sediment supplies had commenced in the middle Miocene when large amounts of clastic Hidaka metamorphic rocks appeared in sedimentary basins in the southern part of the Ishikari-Teshio Belt. Kawakami et al. (2008) showed that a part of the strong contraction was accommodated by thrusting of the Paleogene forearc unit, the Niseu Formation. Not only was the onshore sedimentary basin buried, the southern offshore Hidaka-oki basin was buried rapidly as well with the contemporaneous sediments. Itoh and Tsuru (2005) estimated that the rate of burial (equal to the erosion rate of the Hidaka Mountains) was comparable with that of the recent burial episode linked with intensive arc-arc collision tectonics. As stated by Jolivet and Huchon (1989), the geological structure of Hokkaido suggests that the long-standing transcurrent regime had diminished by the late Miocene. As for the northern part of the Ishikari-Teshio Belt, the timing of the remarkable contraction seems to have been later than that of the southern sector. Itoh et al. (2009) showed that an offshore basin on the eastern margin of the Japan Sea accelerated the subsidence rate during the Quaternary, and a half-graben morphology developed. This is an indication of the emergence of the foreland basin setting (Allen and Allen 2005).

Notwithstanding the prevailing compressive regime, our geological review has clarified that the transcurrent component was still significant in the Neogene basin-forming process. As shown in Figure 7 (right), the Kawabata sedimentary basin in the middle Miocene consists of elongate depocenters aligned in an en echelon shape, which implies that there was an effect of right-lateral wrench deformation.

\section{Sense of lateral motion since the Cretaceous}

As mentioned before, the structural architecture of the forearc of northeast Japan and the Paleogene basin configuration in central Hokkaido have a tendency towards 


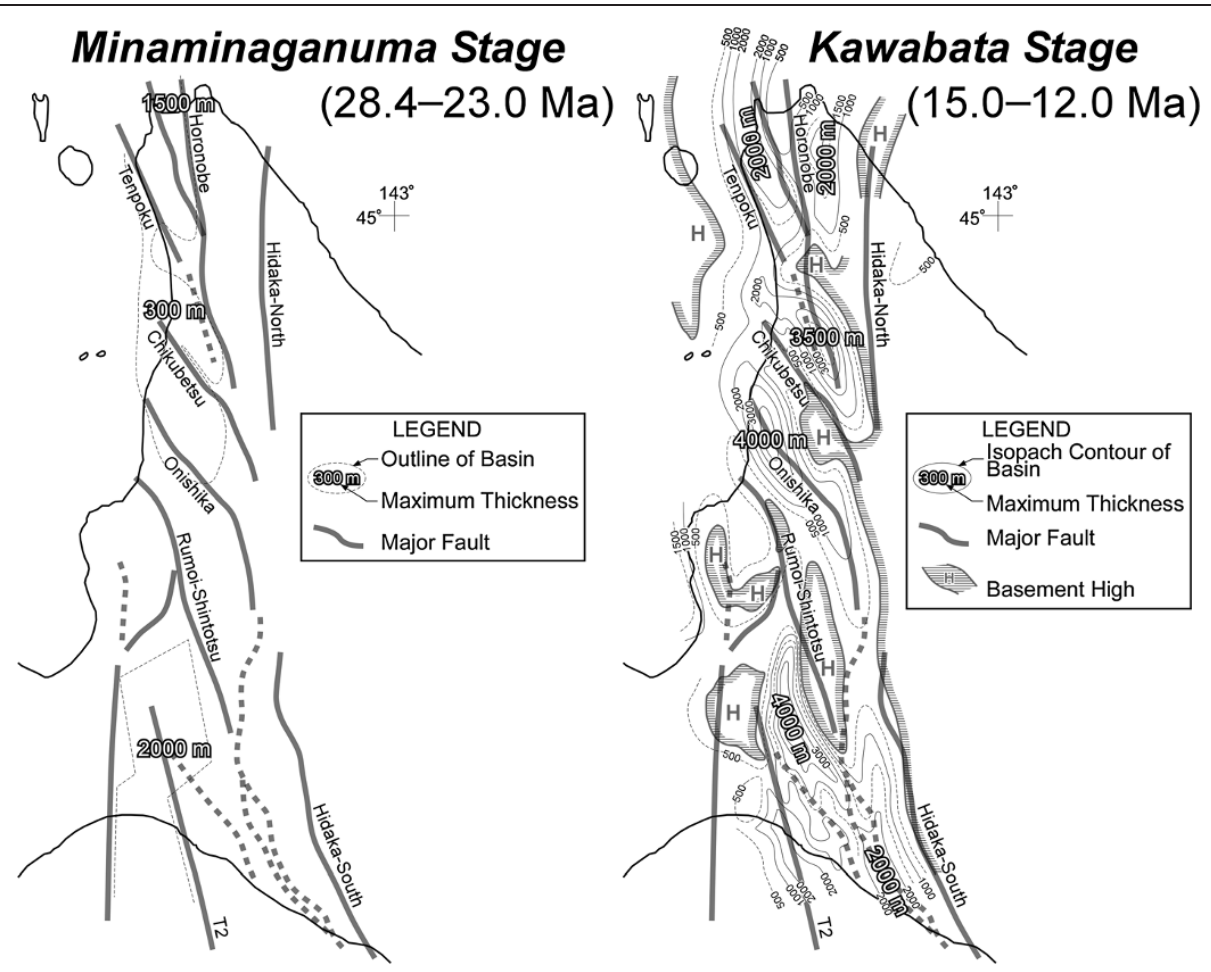

Figure 7 Configuration of sedimentary basins in the Minaminaganuma stage (late Oligocene) and Kawabata stage (middle Miocene). Fault names adopted for numerical modeling are after Kusumoto et al. (2013) and annotated in the figure. Isopach map of the Kawabata stage is after the Association of Natural Gas Mining and Association for Offshore Petroleum Exploration (1982).

dextral motion on the major arc-parallel faults. This seems, however, contradictory with reconstruction studies of old terranes in the arc that imply a remarkable Cretaceous sinistral displacement and deformation (e.g., Sasaki 2003), and the tectonic model of Otsuki (1992) that adopted left-lateral transportation of crust blocks along the continental margin.

Based on paleomagnetism and thermochronology of the subsurface Cretaceous granodiorite obtained from the Kamaishi Mine (Figure 1), Itoh et al. (2000) stated that a part of northeast Japan had experienced episodic counterclockwise $(\mathrm{CCW})$ rotation during the mid-Cretaceous. Figure 8 presents their paleomagnetic results. Multicomponent remanent magnetization was acquired during slow cooling of an enormous plutonic body, and the recorded CCW rotation (Figure 8a) was closely related to the contemporaneous rapid northerly Izanagi Plate motion (Figure $8 \mathrm{~b}$ ) and the strong left-lateral shearing on the Eurasian margin. Although such an episodic governance of the Izanagi Plate may range from 130 to $85 \mathrm{Ma}$ at the maximum duration (Engebretson et al. 1985), a realistic estimate needs to be based on paleoreconstruction of the continental margin through further tectonic investigations.

On comparison with the east Eurasian paleomagnetic reference in Sikhote Alin (Figure 8a; Otofuji et al. 2003),
Itoh and Amano (2004) pointed out the presence of clockwise $(\mathrm{CW})$ rotation in later periods (Figure 8a). They performed detailed paleomagnetic and structural analyses along the sampling route and found that complicated block rotation since the Cretaceous was governed by a north-trending dextral shear (Figure 8c). Thus, dextral deformation and CW rotation dominantly occurred on the forearc after the demise of the Izanagi Plate. Itoh and Tsuru (2006) inferred a similar rotation sequence (CCW to $\mathrm{CW}$ ) in the offshore basin of northeast Japan based on remanence directions of the late Cretaceous and Eocene oriented core samples in a deep borehole (MITI Sanriku-oki in Figure 1).

\section{Duration of strike-slip motion: dislocation modeling of basin formation}

Our basin study has shown that a wrench deformation occurred in central Hokkaido even under the emergence of the compressive regime in the Miocene. Hence, for semi-quantitative evaluation of the transition of regional tectonic regimes, we attempted to restore the Kawabata sedimentary basin in the middle Miocene on the basis of numerical modeling.

In this study, we used dislocation modeling to restore the vertical displacement pattern formed by a bunch of strike-slip faults. Dislocation modeling is a superposition 

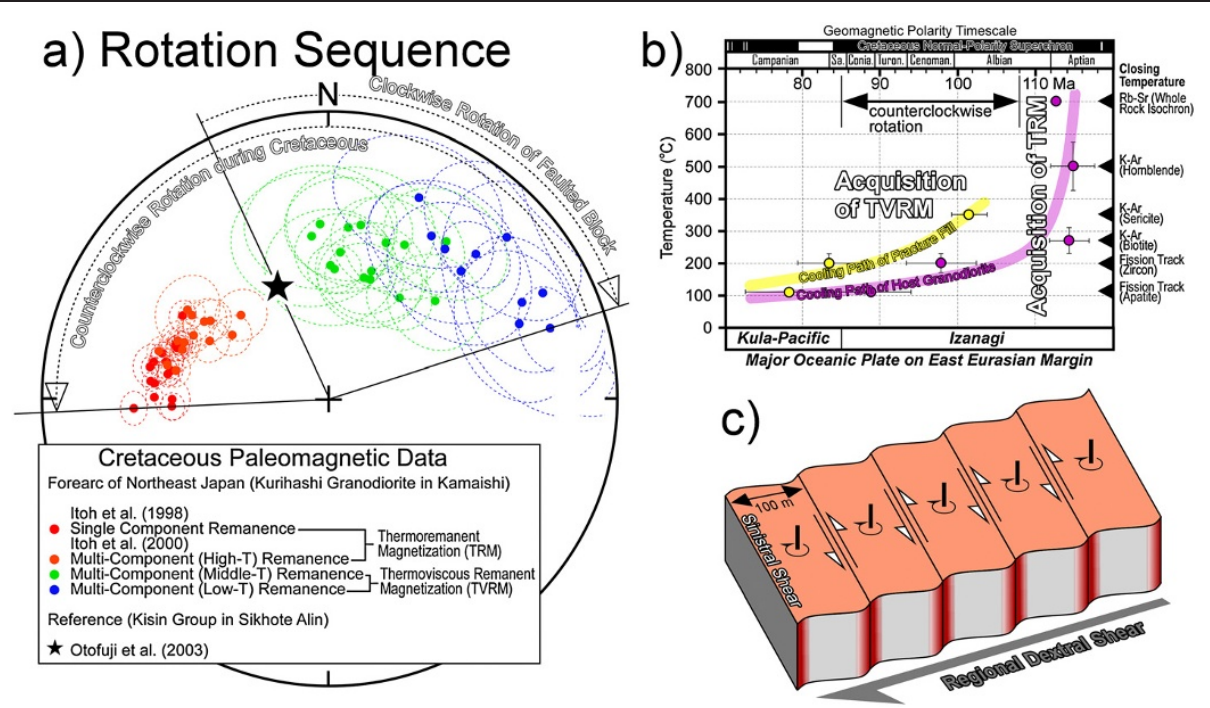

Figure 8 Rotation sequence on the forearc of northeast Japan based on paleomagnetic studies. (a) Site-mean multi-component remanence directions obtained from the Kurihashi Granodiorite in the Kamaishi Mine (Figure 1) after Itoh et al. (1998, 2000). Dotted ovals show the $95 \%$ limit of confidence. All data are plotted on the lower hemisphere of the equal-area net. (b) Cooling and remanence acquisition pattern of the Kurihashi Granodiorite after Itoh et al. (2000). Subduction history of major oceanic plates on the east Eurasian margin is after Engebretson et al. (1985). (c) A model of differential rotation of crustal blocks after Itoh and Amano (2004).

of an analytical solution for dislocation planes embedded in an elastic isotropic half space (Rodgers 1980), and it is advantageous in that the simple calculation represents the essential characteristics of the structural pattern without the assumption of a dynamic frictional constant over the fault plane (Kusumoto et al. 1999, 2001). For the calculation, Okada's dislocation plane (Okada 1985) was adopted. Optimized modeling parameters of the present study are shown in Table 2. The Poisson's ratio and Young's modulus of the medium were taken to be 0.4 and $75 \mathrm{GPa}$, respectively. In Okada's formula (Okada 1985), the Poisson's ratio is included as the only elastic constant, and we employed 0.4 as its magnitude. When numerical simulations based on the elastic theory are applied to geological problems, high Poisson's ratio such as 0.4 to 0.5 has been employed frequently (e.g., Katzman et al. 1995; Tamaki et al. 2010). In this study, we expressed fault motion in the geological timescale by fault motions and propagations of 100 times. We modeled fault propagations as migration of fault terminations, and its migration rate was given by $1 / 100$ of the total dislocation shown in Table 2.

Figure 9 presents the results of numerical modeling. For comparison, the generally conceived compressional model (Figure 9a,b) and our hybrid transpressional model (Figure 9c) are juxtaposed in the figure. It is obvious that

Table 2 Fault parameters of each fault for the Kawabata stage

\begin{tabular}{|c|c|c|c|c|c|c|c|}
\hline \multirow[t]{2}{*}{ Fault zone (ID in Figure 9) } & \multicolumn{3}{|c|}{ Components of dislocation (km) } & \multicolumn{4}{|c|}{ Fault parameters } \\
\hline & Strike-slip & Dip slip & Tensile & $L(\mathrm{~km})$ & $W(\mathbf{k m})$ & $d(\mathrm{~km})$ & $\delta\left(^{\circ}\right)$ \\
\hline \multicolumn{8}{|l|}{ Early stage (transpression) } \\
\hline $\mathrm{T} 2(\mathrm{a})$ & 22.98 & 0.0 & 0.0 & 500.00 & 15.0 & 15.0 & 90.0 \\
\hline $\mathrm{T} 2$ (b) & 48.73 & 0.0 & 0.0 & 500.00 & 15.0 & 15.0 & 90.0 \\
\hline Rumoi-Shintotsu (c) & 48.73 & 0.0 & 0.0 & 63.13 & 15.0 & 15.0 & 90.0 \\
\hline Chikubetsu (d) & 21.96 & 0.0 & 0.0 & 29.09 & 15.0 & 15.0 & 90.0 \\
\hline Horonobe (e) & 35.34 & 0.0 & 0.0 & 70.69 & 15.0 & 15.0 & 90.0 \\
\hline Tenpoku ( $)$ & 35.34 & 0.0 & 0.0 & 30.84 & 15.0 & 15.0 & 90.0 \\
\hline \multicolumn{8}{|l|}{ Late stage (compression) } \\
\hline Hidaka-north (g) & 0.00 & 2.5 & 0.0 & 500.00 & 17.32 & 15.0 & 60.0 \\
\hline Hidaka-south (h) & 0.00 & 2.5 & 0.0 & 216.72 & 17.32 & 15.0 & 60.0 \\
\hline
\end{tabular}

Nomenclature of fault zones is after Kusumoto et al. (2013). Positive strike-slip and dip slip components correspond to right-lateral slip and reverse slip, respectively, with $0<\delta<\pi / 2$. $L, W, d$, and $\delta$ represent the length, width, depth, and dip of the fault, respectively. 


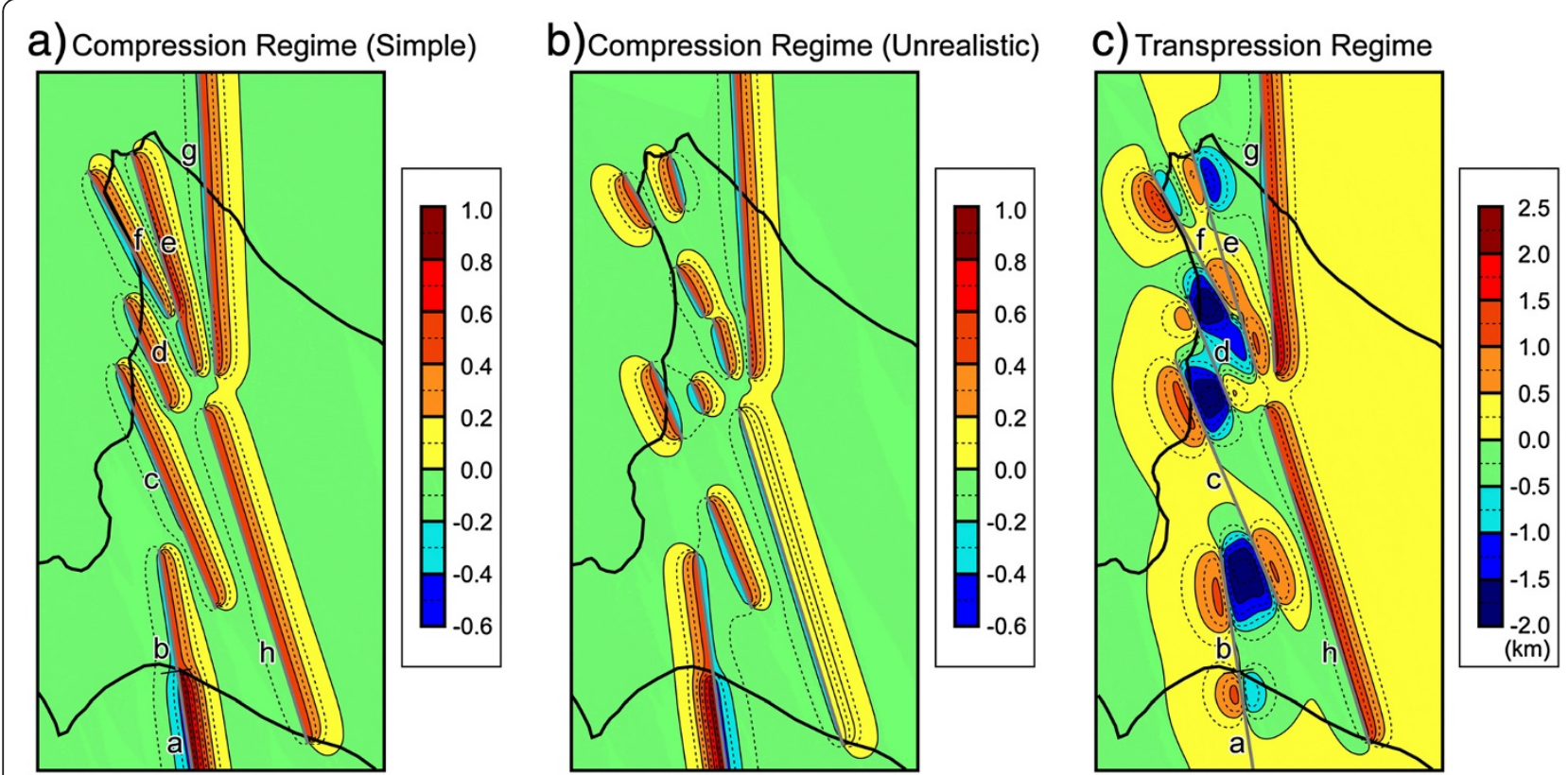

Figure 9 Results of dislocation modeling of the Kawabata sedimentary basin. (a) Simulation based on a simple compressive regime. (b) Compressive model based on unrealistic fault distribution. (c) Simulation based on a transpressional regime assuming propagation of fault terminations. Names of fault abbreviations and optimized fault parameters are given in Table 2. Fault names adopted for numerical modeling are after Kusumoto et al. (2013).

the simplest model (Figure 9a) that assumes uniform reverse motion on the modeled faults (with a dip angle of $60^{\circ}$ ) cannot restore the real basin morphology in the Kawabata stage. In order to fit the pattern of vertical deformation, an unrealistic distribution of reverse faults has to be assumed as shown in Figure 9b. It is also noted that the calculated size of the depression was too small compared with that of the actual basins. On the contrary, a hybrid model (Figure 9c; early dextral slip on the en echelon faults and late reverse slip on the Hidaka faults) that assumed propagation of fault terminations was able to restore the complicated Neogene basin arrangement successfully (see Figure 7).

\section{Mass balance on the convergent margin}

The Japan Trench is well-known as a typical consuming plate margin governed by the subduction erosion process. In previous studies, the rate of subduction erosion was estimated on the assumption that the Pacific Plate had been steadily subducting underneath northeast Japan (e.g., von Huene and Lallemand 1990; von Huene et al. 1994). However, our model of pull-apart basin formation indicates a considerable amount of south-southeastward migration of the forearc sliver. Itoh and Tsuru (2006) assumed more than $200 \mathrm{~km}$ of total migration on the basis of a reconstruction of the conspicuous geomagnetic anomaly on the forearc region. Such migration would have caused thrusting sliver toward the plate boundary and an increased rate of convergence between the oceanic and continental plates. Remarkable forearc unconformity linked with transcurrent faulting may be provoked by such tectonism. Temporal change in subduction erosion rate and mass balance on the Asian convergent margin should be considered on the basis of further integrated basin analyses.

\section{Conclusions}

Based on geological, geochemical, and geophysical approaches, the complicated processes of the Cenozoic basin formation in central Hokkaido have been elucidated as follows:

(1) Long-standing subduction of an oceanic plate provoked basin formation on the forearc region including central Hokkaido throughout the Paleogene.

(2) The oblique mode of subduction resulted in compartmentalization of the Paleogene basins and occasional erosion events.

(3) A compressive tectonic episode since the end of Paleogene was reflected as exhumation of the Paleogene basins and emergence of the foreland setting.

(4) Middle Miocene basin morphology in central Hokkaido was successfully reproduced by assuming hybrid fault motions; these included initially right-lateral and subsequently reverse motions in the longitudinal fault zone.

(5) Except for an episodic left-lateral motion event during the Cretaceous, dominant right-lateral slip upon the northeastern Japanese forearc controlled the longstanding basin-forming process until the middle Miocene. 


\section{Competing interests}

The authors declare that they have no competing interests.

\section{Authors' contributions}

$\mathrm{YI}$ evaluated the paleomagnetic data, compiled the tectonic overview, and drafted the manuscript. OT carried out the geochemical modeling for borehole data and provided regional geological information. SK performed the dislocation modeling of basin formation. MT carried out the geochemical analyses and modeling of surface samples. All authors read and approved the final manuscript.

\section{Acknowledgements}

The authors thank the Japan Petroleum Exploration Co. Ltd. (JAPEX) and Japan Oil, Gas, and Metals National Corporation (JOGMEC) for permission to publish this work. We are greatly indebted to S. Okubo, A. Obuse, late Y. Kajiwara, and N. Takeda for their helpful instructions during the course of geochemical analyses in the JAPEX Research Center. Thanks are also owed to $\mathrm{H}$. Kurita for providing us with geological information for sampling routes in Urakawa. Constructive comments by two anonymous reviewers greatly helped to improve an early version of the manuscript.

\section{Author details}

${ }^{1}$ Department of Physical Science, Graduate School of Science, Osaka Prefecture University, Gakuencho 1-1, Naka-ku, Sakai, Osaka 599-8531, Japan. ${ }^{2}$ JAPEX Research Center, Japan Petroleum Exploration Co. Ltd., 1-2-1, Hamada, Mihama-ku, Chiba 261-0025, Japan. ${ }^{3}$ Graduate School of Science and Technology for Research, University of Toyama, Gofuku 3190, Toyama 930-8555, Japan. ${ }^{4} J a p a n$ Oil Engineering Co. Ltd., Kachidoki 1-7-3, Chuo-ku, Tokyo 104-0054, Japan.

\section{Received: 6 January 2014 Accepted: 15 March 2014}

Published: 22 April 2014

\section{References}

Allen PA, Allen JR (2005) Basin analysis: principles and applications, 2nd edn. Blackwell, Oxford

Ando H (2003) Stratigraphic correlation of Upper Cretaceous to Paleocene forearc basin sediments in Northeast Japan: cyclic sedimentation and basin evolution. J Asian Earth Sci 21:921-935

Association of Natural Gas Mining and Association for Offshore Petroleum Exploration (1982) Petroleum and natural gas resources of Japan. Association of Natural Gas Mining and Association for Offshore Petroleum Exploration, Tokyo

Dickinson WR (1995) Forearc basins. In: Busby C, Ingersoll R (eds) Tectonics of Sedimentary Basins, chapter 6. Blackwell, Massachusetts

Dickinson WR, Seely DR (1979) Structure and stratigraphy of forearc regions. AAPG Bull 63:2-31

Engebretson DC, Cox A, Gordon RC (1985) Relative motions between oceanic and continental plates in the Pacific Basin. Geol Soc Am Spec Paper 206:1-59

Fitch TJ (1972) Plate convergence, transcurrent faults, and internal deformation adjacent to southeast Asia and the western Pacific. J Geophys Res 77:4432-4460

Gradstein FM, Ogg JG, Schmitz MD, Ogg GM (2012) The Geologic Time Scale 2012. Elsevier, Amsterdam

lijima A (1959) On relationship between the provenances and the depositional basins, considered from the heavy mineral associations of the Upper Cretaceous and Tertiary formations in central and southeastern Hokkaido, Japan. J Fac Sci Univ Tokyo (Sec 2) 11:339-385

Itoh Y, Amano K (2004) Progressive segmentation and systematic block rotation within a plutonic body: palaeomagnetism of the Cretaceous Kurihashi granodiorite in northeast Japan. Geophys J Int 157:128-140

Itoh Y, Tsuru T (2005) Evolution history of the Hidaka-oki (offshore Hidaka) basin in the southern central Hokkaido, as revealed by seismic interpretation, and related tectonic events in an adjacent collision zone. Phys Earth Planet Int 153:220-226

Itoh Y, Tsuru T (2006) A model of late Cenozoic transcurrent motion and deformation in the fore-arc of northeast Japan: constraints from geophysical studies. Phys Earth Planet Int 156:117-129

Itoh Y, Amano K, Danhara T (1998) Rotational motion of the Kurihashi Granodiorite distributed in the Kamaishi Mine, northeast Japan, inferred from paleomagnetic analyses. J Geol Soc Japan 104:42-51
Itoh Y, Amano K, Danhara T (2000) Paleomagnetism, rock magnetism, and fission track dating of the Kurihashi Granodiorite in northeast Japan: evidence for a Cretaceous hydrothermal event and differential rotation along the eastern Eurasian margin. J Geophys Res 105:13519-13532

Itoh Y, Ishiyama T, Nagasaki Y (2005) Deformation mode in the frontal edge of an arc-arc collision zone: subsurface geology, active faults and paleomagnetism in southern central Hokkaido, Japan. Tectonophysics 395:81-97

Itoh Y, Kusumoto S, Maeda J (2009) Cenozoic basin-forming processes along the northeastern margin of Eurasia: constraints determined from geophysical studies offshore of Hokkaido, Japan. J Asian Earth Sci 35:27-33

Japan National Oil Corporation (JNOC) (1974) Report on the Geophysical Survey "Shimokita-Kitakami", Fiscal Year 1973. Japan National Oil Corporation, Tokyo

Jolivet L, Huchon P (1989) Crustal-scale strike-slip deformation in Hokkaido, northern Japan. J Struct Geol 11:509-522

Katzman R, ten Brink US, Lin J (1995) Three-dimensional modeling of pull-apart basins: implications for the tectonics of the Dead Sea Basin. J Geophys Res 100:6295-6312

Kawakami G, Kawamura M, Arita K (2002) Finding of metamorphic rock fragments in rhyolitic tuff beds of the Oligocene Momijiyama Formation, central Hokkaido, Japan: implications in the Paleogene tectonism of central Hokkaido. J Geol Society Japan 108:235-248

Kawakami G, Ishimaru S, Tajika J, Ohtsu S, Sato H, Abe T, Kanno M, Nagasaka A (2008) Lithology and tectono-stratigraphic relationship between the Eocene Niseu Formation and the middle Miocene formations in the upper reaches of the Appetsugawa River, frontal Hidaka collision zone, central Hokkaido, Japan (a preliminary report). Earth Sci (Chikyu Kagaku) 62:17-28

Kurita H (2010) Tenpoku-Haboro area. In: Niida K, Arita K, Kato M (eds) Regional Geology of Japan, 1. Hokkaido, Section 3.2, Asakura, Tokyo

Kurita H, Yokoi S (2000) Cenozoic tectonic settings and a current exploration concept in southern central Hokkaido, northern Japan. J Japan Assoc Petrol Tech 65:58-70

Kusumoto S, Takemura K, Fukuda Y, Takemoto S (1999) Restoration of the depression structure at the eastern part of central Kyushu, Japan by means of dislocation modeling. Tectonophysics 302:287-296

Kusumoto S, Fukuda Y, Takemura K, Takemoto S (2001) Forming mechanism of the sedimentary basin at the termination of the right-lateral left-stepping faults and tectonics around Osaka Bay. J Geography 110:32-43

Kusumoto S, Itoh Y, Takano O, Tamaki M (2013) Numerical modeling of sedimentary basin formation at the termination of lateral faults in a tectonic region where fault propagation has occurred. In: Itoh $Y$ (ed) Mechanism of sedimentary basin formation: multidisciplinary approach on active plate margins. InTech, Rijeka, http://dx.doi.org/10.5772/56558. Accessed 6 January 2014

Lallemand S, Jolivet L (1985) Japan Sea: a pull-apart basin? Earth Planet Sci Lett 76:375-389

Miyasaka S, Hoyanagi K, Watanabe Y, Matsui M (1986) Late Cenozoic mountainbuilding history in central Hokkaido deduced from the composition of conglomerate. Monogr Assoc Geol Collab Japan 31:285-294

Niida K (1992) Basalts and dolerites in the Sorachi-Yezo Belt, central Hokkaido, Japan. J Fac Sci Hokkaido Univ (Ser 4) 23:301-319

Okada Y (1985) Surface deformation due to shear and tensile faults in a half-space. Bull Seismol Soc America 75:1135-1154

Okamura S, Yahata M, Nishido H, Ibusuki A, Yokoi S, Yonejima M, Imayama T, Maeda J (2010) K-Ar ages and petrology of the Takinoue stage volcanic rocks in central Hokkaido, Japan: geochemistry of volcanic rocks that form a shallow reservoir in the Yufutsu oil and gas field. J Geol Soc Japan 116:181-198

Osawa M, Nakanishi S, Tanahashi M, Oda H (2002) Structure, tectonic evolution and gas exploration potential of offshore Sanriku and Hidaka provinces, Pacific Ocean, off northern Honshu and Hokkaido, Japan. J Japan Assoc Petrol Tech 67:38-51

Otofuji Y, Matsuda T (1983) Paleomagnetic evidence for the clockwise rotation of Southwest Japan. Earth Planet Sci Lett 62:349-359

Otofuji Y, Kambara A, Matsuda T, Nohda S (1994) Counterclockwise rotation of Northeast Japan: paleomagnetic evidence for regional extent and timing of rotation. Earth Planet Sci Lett 121:503-518

Otofuji Y, Matsuda T, Enami R, Uno K, Nishihama K, Halim N, Su L, Zaman H, Kulinich RG, Zimin PS, Matunin AP, Sakhno VG (2003) Late Cretaceous palaeomagnetic results from Sikhote Alin, far eastern Russia: tectonic implications for the eastern margin of the Mongolia Block. Geophys J Int 152:202-214 
Otsuki K (1992) Oblique subduction, collision of microcontinents and subduction of oceanic ridge: Their implications on the Cretaceous tectonics of Japan. Is| Arc 1:51-63

Rodgers DA (1980) Analysis of pull-apart basin development produced by en echelon strike-slip faults. In: Ballance PF, Reading HG (eds) Sedimentation in oblique-slip mobile zones, special publications of the International Association of Sedimentologists, No. 4. Blackwell, Oxford

Sakai A, Kanie Y (1986) Geology of the Nishicha district, with geological sheet map at 1:50,000. Geological Survey of Japan, Tsukuba

Sasaki M (2003) Early Cretaceous sinistral shearing and associated folding in the South Kitakami Belt, northeast Japan. Isl Arc 12:92-109

Suzuki N, Matsubayashi H, Waples DW (1993) A simpler kinetic model of vitrinite reflectance. AAPG Bull 77:1502-1508

Sweeney JJ, Burnham AK (1990) Application of a simple model of vitrinite reflectance based on chemical kinetics. AAPG Bull 74:1559-1570

Takano O, Waseda A (2003) Sequence stratigraphic architecture of a differentially subsiding bay to fluvial basin: the Eocene Ishikari Group, Ishikari Coal Field, Hokkaido, Japan. Sediment Geol 160:131-158

Takano O, Itoh Y, Kusumoto S (2013) Variation in forearc basin configuration and basin-filling depositional systems as a function of trench slope break development and strike-slip movement: examples from the Cenozoic Ishikari-Sanriku-Oki and Tokai-Oki-Kumano-Nada forearc basins, Japan. In: Itoh $Y$ (ed) Mechanism of sedimentary basin formation: multidisciplinary approach on active plate margins. InTech, Rijeka, http://dx.doi.org/10.5772/ 56751. Accessed 5 March 2014

Takashima R, Kawabe F, Nishi H, Moriya K, Wani R, Ando H (2004) Geology and stratigraphy of forearc basin sediments in Hokkaido, Japan: Cretaceous environmental events on the north-west Pacific margin. Cret Res 25:365-390

Takeuchi T, Kodama K, Ozawa T (1999) Paleomagnetic evidence for block rotations in central Hokkaido-south Sakhalin, Northeast Asia. Earth Planet Sci Lett 169:7-21

Tamaki M, Oshimbe S, Itoh Y (2008) A large latitudinal displacement of a part of Cretaceous forearc basin in Hokkaido, Japan: paleomagnetism of the Yezo Supergroup in the Urakawa area. J Geol Soc Japan 114:207-217

Tamaki M, Tsuchida K, Itoh Y (2009) Geochemical modeling of sedimentary rocks in the central Hokkaido, Japan: episodic deformation and subsequent confined basin-formation along the eastern Eurasian margin since the Cretaceous. J Asian Earth Sci 34:198-208

Tamaki M, Kusumoto S, Itoh Y (2010) Formation and deformation processes of late Paleogene sedimentary basins in southern central Hokkaido, Japan: paleomagnetic and numerical modeling approach. Is Arc 19:243-258

Tatsumi Y, Otofuji Y, Matsuda T, Nohda S (1989) Opening of the Sea of Japan back-arc basin by asthenospheric injection. Tectonophysics 166:317-329

Ueda H, Kawamura M, Niida K (2000) Accretion and tectonic erosion processes revealed by the mode of occurrence and geochemistry of greenstones in the Cretaceous accretionary complexes of the Idonnappu Zone, southern central Hokkaido, Japan. Isl Arc 9:237-257

von Huene R, Lallemand S (1990) Tectonic erosion along the Japan and Peru convergent margins. Geol Soc America Bull 102:704-720

von Huene R, Klaeschen D, Cropp B, Miller J (1994) Tectonic structure across the accretionary and erosional parts of the Japan Trench margin. J Geophys Res 99:22349-22361

doi:10.1186/2197-4284-1-6

Cite this article as: Itoh et al:: Mechanism of long-standing Cenozoic basin formation in central Hokkaido: an integrated basin study on an oblique convergent margin. Progress in Earth and Planetary Science 2014 1:6.

\section{Submit your manuscript to a SpringerOpen ${ }^{\circ}$ journal and benefit from:}

- Convenient online submission

- Rigorous peer review

- Immediate publication on acceptance

- Open access: articles freely available online

- High visibility within the field

- Retaining the copyright to your article

Submit your next manuscript at $\gg$ springeropen.com 